\title{
The Learning Model Used in the Teaching and Learning Process of Environmental Damage in Bandung Basin
}

\author{
Dede Sugandi ${ }^{1, *}$, Nanin $\operatorname{Trianawati}^{1} \&$ Lili. Somantri ${ }^{1}$ \\ ${ }^{1}$ Department of Geography Education, Indonesia University of Education, Bandung, \\ Indonesia \\ *Correspondence: Department of Geography Education, Indonesia University of Education, \\ Bandung, Indonesia. E-mail: dedesugandi@upi.edu
}

Received: July 5, 2017 Accepted: August 2, 2017 Published: August 9, 2017

doi:10.5296/ije.v9i3.11499 URL: https://doi.org/10.5296/ije.v9i3.11499

\begin{abstract}
The impacts of environmental damage, such as floods, should be introduced to students in the school teaching and learning. The study aims to: Find out the factors causing floods in Bandung and analyse the teaching and learning models in understanding the impact of environmental damage. To raise awareness and understanding of the learning process is done by bringing students to the flood scene location with Pre-Experimental Designs learning model. The media used to use video, images and textbook about the flood. This stage is carried out pre-test to the student. This phase is compared with the flood of students to the scene and given an explanation and asked to interview the student communities affected by flooding. After the interviews were conducted Post-test group. It employed the Pre-experimental design model with a sample of 88 students who were divided into 11 groups. The techniques of analysis conducted by providing pre-test and post-test on Students to determine comprehension and students conduct interviews with affected communities.
\end{abstract}

With this model is expected that students can know, understand, and become skilled in revealing evidences from the field regarding how floods occur, the causing factors and its impacts. In the pre-test conducted on students showed mixed results with an average value of 4.94, while the Post-test with an average value of 7:37. The result of the application of the Pre-Experiment design illustrates that students are given learning material and taken to the scene of flooding showed an increase understanding, awareness. This is due to the emotions students affected because of the stories and interviews with people affected by floods. Applied learning models to increase understanding and awareness of environmental destruction can also develop a concern for environmental sustainability. In addition, the study would like to find the stages in the teaching and learning process and how students are engaged emotionally in the process of gaining the knowledge, understanding, and skills. A learning model that engages students emotionally is believed to be able to develop their logic.

Keywords: environment damage, flood, emotionally, teaching and learning model, pre-experiment design, emotionally 


\section{Introduction}

The development is oriented towards increasing the people's ability and potentials. In reality, development also impacts on the environment, as it is related to land uses changes. Thus, sustainable development becomes vital for the balance between development and environmental equilibrium. Sustainable development is a pattern of resource use that aims to meet human needs while preserving the environment so that these needs can be met not only in the present, but in the indefinite future: Sustainability is a process which tells of a development of all aspects of human life affecting sustenance (Sefouhi et.al., 2010). Human beings live in a certain area to meet their needs. In order to meet their needs, human beings have to utilize the land, causing disturbance to the stability and equilibrium of the environment (Iskandar \& Sugandi, 2015). Without sustainable development, the environment will be damaged; for instance, the uncontrolled expansion of urban centres and intensive cultivation of rice (Linn and Rolim, 2015). Study also forest shrinkage, as another example of environmental damage, is caused by the change in its use into mixed gardens and open lands, while the shrinkage of mixed gardens and rice fields is due to the use of these areas for settlement and industries' (Rushayati et.al, 2012; Adibah et.al, 2013). Land uses to meet people's needs cause a decline in the carrying capacity of the environment for sustainability. Study demonstrated that achieving sustainable development requires collaboration between different sectors and institutions, as well as the participation of all relevant stakeholders and individuals" (Wiryono, 2007; Mohsen et.al, 2013).

\subsection{Environmental Damage}

Study demonstrated that 'Environmental damage is caused by disequilibrium in the environment. The damage cannot be seen at a glance. The declining quality of the environment or ecosystem is increasingly felt, and its impacts are felt either directly or indirectly in the economic, social, and cultural aspects of life' (Sukojo, 2003; Smith and Ward, 1998). The main cause for floods is the damage made by humans to the environment; for example, the flood and waterlogged disasters in the Dongting Lake are due to the influence of artificial and natural factors such as abnormal atmospheric circulation and influence of land use change. Gradual loss of biodiversity and disturbances in ecological balance are due to the ecological succession from sand deposit to vegetation' (Habiyakare et.al., 2015). Meanwhile, predicted flood hazard zones are largely based on mathematical or statistical theory and use the historical record of the past events to estimate the future probability or recurrence of similar events' (Alaghmand et. al., 2012). Changes in land uses also contribute to the occurrence of floods. Indeed, land cover changes can have four major direct (or first-order) impacts on the hydrological cycle and water quality; they can cause floods, droughts, and changes in rivers and ground water regime; and they can affect water quality' (Meyer \& Turner, 1998; Prasena and Shrestha study, 2013).

Flood is commonly caused by an increase in the surface runoff, while runoff itself is caused by the lack of rainfall infiltration that is eventually accumulated on the surface and flows to the lower areas. Studied about runoff showed that 'runoff is frequently accumulated on a watershed. The Hydrological response unit that divides the watershed into various 
homogeneous units based on the land use, soil type, and slope at each grid (Shivhare, V et.al, 2014; Duffková, 2008; Haque, 2000).

\subsection{Student Teaching and Learning Process}

Learning is a process of transferring knowledge to students through teaching and learning process. Ndofirepi and Cross (2014) explained that knowledge materialises from a complex process that relates to social, situational, cultural, and institutional dynamics. In their daily lives, people classify, cipher, process, and assign meaning to their experiences, thereby defining their everyday forms of knowledge". Social transformation sits at the extreme end of conceptions of social change with universities frequently deemed as key institutions in the processes of social change and development' (Brennan and Lebeau, 2004). It was found that the role of scientific explanation in the didactic system of developing education in the new information environment is the development of students forming their scientific outlook, logical thinking, and culture of information activities" (Suriya et.al., 2015). To develop teaching and learning, local contents should be the sources for students. In this way, students will be encouraged to get involved in solving the problems related to environmental preservation.

The impacts of environmental damage should be known and understood by people; therefore, education should include environmental preservation in the teaching and learning process. In order to include the topic of environmental damage in the teaching and learning process, the sub-topics of environment and impacts of environmental damage, especially floods, should be covered in the curriculum. Since the constructivist learning approach was taken as a basis while designing the modular curriculum for environmental education, multiple measurement $\&$ evaluation techniques were used for the evaluation of the students. Result study demonstrated that the fact that the questions in the modular curriculum were applicable \& that the questions were deductive \& appropriate to the subjects is obvious in the statement made by SÜ2" (Artun and Özsevgeç, 2016). The education promoting awareness of environmental damage is not only given formally in the schools, also environmental non-profit organizations also conduct environmental education on the problems and even cooperate with government authorities. The nature of such associations is exclusively peaceful and voluntary, nor is the goal to acquire profit' (Aitimova et.al., 2016). Then 'with the knowledge and understanding of the importance of the environment for life, students will understand that life and development is influenced by sustainable environment. The success of education in promoting sustainable development has been proven by the case of Turkey. Turkey comes up against the big changes regarding the sustainable development and the environmental education which is the primary instrument for the sustainable development" (Fettahlığlua et.al, 2016).

The difficulties of making students understand the impacts of floods lie in the nature of the learning that is mostly theoretical and abstract. To start with students should be equipped with the knowledge and skills about the location and morphology of the flooded areas. Follow-up comparisons on the dimensions of science process skills and scientific curiosity were analysed and discussed. The findings of this study will provide a framework for science 
teachers to teach students through interesting and meaningful outdoor activities' (Ting \& Siew, 2014). Then, this is so because the teaching and learning that is only based on theory and textbooks will cause difficulties for students to practice their knowledge in the field. It was also found that media functionality in geography textbooks shows the worst, which is equal of 59.50. It would be bad for the implementation of the national curriculum in 2013 that is currently being used by teachers" (Purwanto et.al, 2016).

\subsection{Aims of Study}

In general, the teaching and learning methods and models employed by teachers are supported by the media such as black/white boards, textbooks, and slideshows. As a result of this limitation in media, students have a lack of understanding about how floods occur. They only know that floods become an obstacle for people in doing their activities. If this continues, students will only accept floods as a result of nature's rage, without understanding how to cope with the problem. In order to create such an understanding, students should not only be given teaching and learning that is theoretical, employing only the whiteboards, textbooks, and teacher's slideshows. They should also be taught with the necessary skills. Thus, the study aims to:

1. Find out the factors that cause the occurrence of floods in Bandung Basin.

2. Analyse the teaching and learning stages of the process of floods as a result of environmental damage.

\section{Methodology}

This study on the teaching and learning process of the impacts of environmental damage employed the Pre-Experimental Designs. Type model used was One-Group Pre-test and Post-test Design. The experiment was conducted to test the appropriate stages to provide students with the knowledge and understanding about floods. The population consisted of Geography Education students, and the sample included those who took the course of Hydrology.

The sample used in this study were 88 students of geography education, which is consist of two classes. To determine the score of pre and post test they divided into 11 groups, which is consist of eight students. Pre-test performed with learning about floods and post-test conducted with treatment on the field. In the application of this model, the stages of Pre-test conducted by providing theory, references, and videos regarding the floods processes. While, the stages of treatment Post-test done by giving an example to read land use changes maps and calculating the volume of land surface run-off. Then, the students should compare the surface run-off water between developed land and undeveloped land. The results of pre-test and post-test is expected to test knowledge and understanding about the impact of environmental damage to the floods. This model is also expected to gain the understanding and emotional involved by the students with learning by doing the flood processes directly from the field. 
Lecturer participants provided teaching and learning materials using the whiteboard, textbooks, and slideshows. In addition, a practicum was done by limiting the flooded areas on the map. To limit the areas on the map, students did a field survey and determined the geographical coordinates. Data of the survey were drawn into a map, resulting in the borders of flooded area.

\section{Results}

In the analysis stage, students prepared a 1:25,000 scale topographic map of Indonesia and a GPS. GPS was needed in order to determine the coordinates at certain latitudes. Rainfall data are the basis of creating the map, making it possible to find the rainfall volumes. Rainfall data were obtained from three stations (Table 1).

Table 1. Average monthly rainfall 2006-2015

\begin{tabular}{ccccccccccccc}
\hline Station & Jan & Feb & Mar & Apr & May & Jun & Jul & Aug & Sept & Oct & Nov & Dec \\
\hline Lembang & 142.1 & 221.9 & 201.8 & 204.1 & 178.5 & 62.2 & 62.0 & 26.9 & 60.8 & 104.5 & 299.0 & 262.3 \\
Cisondari & 142.1 & 170.2 & 158.6 & 151 & 152.6 & 50.7 & 26.2 & 22.4 & 40.2 & 76.3 & 168.4 & 192.3 \\
Cileunca & 241.0 & 268.7 & 266.8 & 265 & 133.8 & 57.9 & 35 & 37 & 52.7 & 118.2 & 292.0 & 336.9 \\
Rainfall & 175.1 & 220.2 & 209.1 & 206.7 & 155.0 & 56.9 & 41.1 & 28.8 & 51.2 & 99.7 & 253.1 & 263.8 \\
Days of R & 16 & 16 & 15 & 16 & 7 & 3 & 2 & 2 & 2 & 4 & 13 & 13 \\
Rain/day & $\mathbf{1 0 . 9}$ & $\mathbf{1 3 . 8}$ & $\mathbf{1 3 . 9}$ & $\mathbf{1 2 . 9}$ & $\mathbf{2 2 . 1}$ & $\mathbf{1 9}$ & $\mathbf{2 0 . 5}$ & $\mathbf{1 4 . 4}$ & $\mathbf{2 5 . 6}$ & $\mathbf{2 4 . 9}$ & $\mathbf{1 9 . 5}$ & $\mathbf{1 9 . 5}$ \\
\hline
\end{tabular}

Source: Agency of Irrigation, Department of Public Work, 2016.

The multiplication of rain thickness with the total area of Bandung Basin results in rainfall volumes. The measurement was concentrated on developed areas, as developed areas lack the ability to infiltrate rain water. Based on the results of monthly rainfall analysis, it was found that rainfall is the factor causing floods.

The rain water pouring on the surface is dispersed by the backs of the mountains or hills. The rain water that fails to infiltrate will get accumulated and flow to the lower area. The surface runoff will be concentrated on lands with flat slopes. This concentration will cause floods. As can be observed from the map, Bandung Basin is bordered by mountains and hills. The rain water that runs off will be concentrated in the lands with flat slopes, namely Bandung Regency. The runoff flows from the areas with steep slopes to those with flat slopes and drains to the river. This means that land slope is also a factor causing concentration of runoff. By considering the possibility of water to flood areas with the same height, an analysis of land use changes was done. The image analysis resulted in total areas of land uses as shown in Table 2. 


\section{MInstitute ${ }^{\text {Mink }}$}

Table 2. Comparison of the Total Areas of Land Use Classes in 2015

\begin{tabular}{llrrrr}
\hline No & Land Use Classes & $\mathbf{2 0 1 0}$ & $\mathbf{2 0 1 5}$ & \multicolumn{2}{c}{ Area Change $\left(\mathbf{k m}^{\mathbf{2}}\right)$} \\
& & Area $\left(\mathbf{K m}^{\mathbf{2}}\right)$ & Area $\left(\mathbf{K m}^{2}\right)$ & Expanding & Shrinking \\
\hline 1 & Settlement and Industries & 458.507 & 535.155 & 76.648 & - \\
2 & Brushes & 121.337 & 129.272 & 7.935 & - \\
3 & Plantations & 82.681 & 85.580 & 2.899 & - \\
4 & Mixed Gardens & 182.685 & 182.489 & - & 196 \\
5 & Forests & 265.927 & 269.243 & - & 16.684 \\
6 & Non-Irrigated Agricultural Lands & 282.569 & 395.448 & 112.8791 & - \\
7 & Rice Fields & 517.791 & 334.310 & - & 183.481 \\
\hline \multicolumn{2}{c}{ Area Total } & $\mathbf{1 9 1 1 . 4 9 8}$ & $\mathbf{1 9 1 1 . 4 9 8}$ & $\mathbf{2 0 0 . 3 6 1}$ & $\mathbf{3 9 6 . 1 6 5}$ \\
\hline
\end{tabular}

The analysis of the images shows land use changes, especially in the developed lands. Developed lands have impervious surface and therefore are unable to infiltrate rainfall. From the total area of developed lands, rainfall volumes and runoff volumes can be calculated. The volumes of runoff will flood lands. Developed lands form impervious surface, as the surface is covered and replaced with walls, concrete, and asphalt. With impervious surface, rain water cannot infiltrate into the ground. This means that land surface infiltration is the causing factor of flood.

The various land use changes in Bandung Basin mean increased area of developed lands. Based on the total area of developed lands, runoff volumes can be calculated. Although in this study only the area of developed lands was measured, it does not mean that other land uses do not cause runoff. Land uses for forests and agriculture were not calculated because such land uses can still infiltrate rain water.

A change in developed lands causes an increase in runoff volume. In 2010, the total area of developed lands was 458,507,000 $\mathrm{m} 2$, resulting in the runoff volume of 11,737,779.20 $\mathrm{m} 3$; meanwhile, in 2015 the total area of developed lands was $535,155,000 \mathrm{~m} 2$, resulting in the runoff volume of $13,699,968.00 \mathrm{~m} 3$. This means that there was an increase in the runoff volume of as much as $76,648,000 \mathrm{~m} 3$. Of all the land uses analysed in the study, the uses that form impervious surface are settlement, industries, roads, and social and public facilities. These land uses with their impervious surfaces have caused the rainfall to run off and created flood. A large concentration of runoff on the plains that forms flood will decrease if the river flow decreases as well.

In the early stage of learning process, the score of pre-test shows not too good because the students only have a material from explanations and learn from the theory or textbooks in the classroom. In the next stage, students bring to area of the disaster to showing the real field of floods occurred. In that place the lecturer explain about the process of floods then shows the situation surrounding area. It was expected to improve knowledge and understanding of student directly from the field. The comparison of the score from pre-test and Post-test results is shown in Figure 1 and Table 3. 


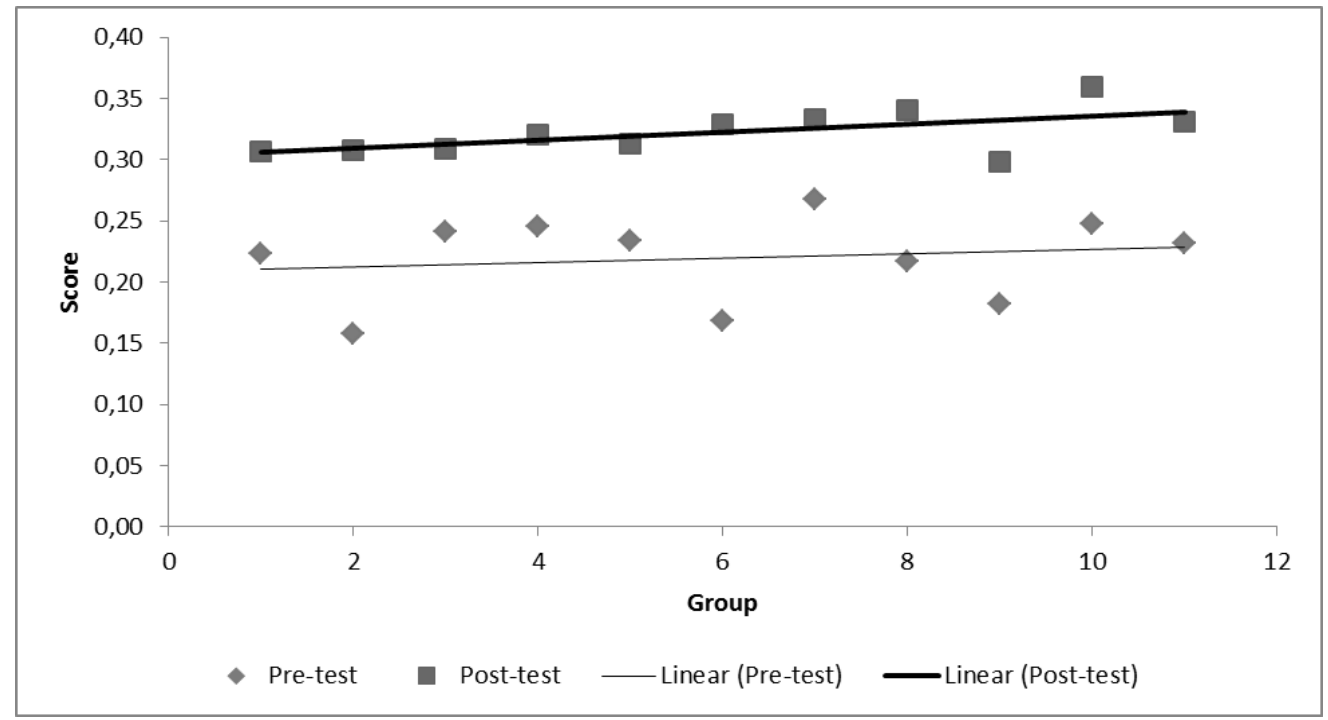

Figure 1. Score Group of Students before and after Pre-Experimental Designs

Table 3. Score Comparison resulted from Pre-test and Pos-test

\begin{tabular}{ccc}
\hline Group students & Pre-test & Post-test \\
\hline 1 & 4.81 & 7.21 \\
2 & 3.47 & 6.83 \\
3 & 5.47 & 7.25 \\
4 & 5.53 & 7.41 \\
5 & 4.97 & 7.30 \\
6 & 4.03 & 7.53 \\
7 & 6.25 & 7.60 \\
8 & 4.72 & 7.70 \\
9 & 4.22 & 6.69 \\
10 & 5.56 & 7.97 \\
11 & 5.34 & 7.56 \\
\hline Mean & $\mathbf{4 . 9 4}$ & $\mathbf{7 . 3 7}$ \\
\hline
\end{tabular}

With the teaching and learning process that follows the formulated stages, students will not be focused on theories and their learning will not be limited by the media of whiteboard, textbooks, and slideshows; instead, they will participate and involve emotionally in understanding the occurrence of environmental damage. Such teaching and learning invites students to determine, measure, analyse, and select the teaching and learning objects. The teaching and learning is also closely related to thinking skills, so that it requires a longer time compared to the common classroom teaching and learning. 


\section{Discussion}

The teaching and learning on environmental damages, especially floods, are concerned with students' knowledge, understanding, skills, and emotions. Both teachers and lecturers commonly use whiteboard, textbooks, and slideshows in the teaching and learning of flood. Such a learning model is indeed easy to do, quick, and does not require much time. However, in this kind of teaching and learning students are not emotionally engaged, and their understanding is only based on textbooks. With practical activities, students will be able to obtain data such as: Rainfall and how to analyse the data, Landsat images and map making, and the changes that will occur in a region made as the object of teaching and learning.

The teaching and learning process of environmental damage should involve several aspects, namely knowledge, understanding, and emotions of the students. Hence, the learning model designed in this study consists of several stages, namely: 1) Preparation stage, in which students will know the materials and tools needed to analyse floods. They will also know about rainfall data, topographic maps, and Landsat images that are made the bases for analysis. They must be able to use the data and tools for the analysis; 2) Interpretation stage: This stage is done by analysing Landsat images to find changes in land uses, developed lands, and land slopes. In this stage, students will interpret the images and analyse land use changes and their impacts. Land use for developed lands will create impervious surface, so that rain water cannot infiltrate and forms runoff. The volumes of runoff will be measured by students, thereby requiring them to understand the function of land surface and its interaction with water. They will also know about runoff movements and where the runoff will get concentrated; 3) Field survey stage, in which students are required to observe flooded areas, so that they will know and understand how floods occur because of the rain water that fails to infiltrate into the ground. Knowing the concentration of runoff, students will be able to determine and decide the factors causing floods; and 4) Reporting stage: At this stage, students show the outcomes of the teaching and learning process. The outcomes are discussed with classmates in order to draw conclusions and make decisions.

The use of Pre-Experimental Designs show changes in increasing of knowledge and understanding. It is due to the direct observation to the real field of floods occurred can involve students mentally and emotionally. The Pre experimental design model proposed by Cunningham AE, et al (2016) that Pre- and post-test analyzes revealed significant changes in teachers' phonological awareness abilities, content knowledge, and pedagogical knowledge. Increases the pharmacy awareness activities in the classroom. Through such a learning model, with the particular stages, students will be emotionally engaged in the process of acquiring knowledge, and their understanding will form thinking patterns. They will have the ability to think logically in between measurement, analysis, and field survey. Thinking logically will help students determine and decide the impacts of environmental damage and the factors causing floods. 


\section{Conclusion}

The impacts of environmental damage, which in this case is in the form of flood, should be understood by students, so that they can maintain and sustain the environment. This is so because life sustainability is highly influenced by environmental sustainability.

Hence, based on this study it can be concluded that students can know and understand the factors causing floods: The larger the volumes of rainfall, the greater the runoff volumes. Water infiltration will decrease in line with the increasing area of impervious surfaces/layers. Developed lands are impervious, thereby runoff will be found on these areas. The teaching and learning process of the impacts of environmental damage, namely flood, does not only involve students' knowledge and understanding, but also their emotion. Thus, the learning model recommended based on this study is one that consists of the following stages: Preparation, image analysis, measurement of rainfall and runoff volumes, field survey, and reporting. The use of Pre-Experimental Designs models can improve students' knowledge and understanding.

\section{Acknowledgments}

The author would like to express his gratitude to Prof. Dr. Asep Kadarohman and Prof Dr. Didi Sukyadi for his guidance and help in the writing of this journal. I would like to thank the editor for this kind help.

\section{References}

Adibah, N., Kahar, S., \& Sasmito, B. (2013). Aplikasi Penginderaan Jauh Dan Sistem Informasi Geografis Untuk Analisis Daerah Resapan Air. Jurnal Geodesi Universitas Diponogoro, 2(2), 143-153.

Agency of Irrigation. (2016). Rainfall Data. Department of Public Work, Bandung West Jawa.

Aitimova, B.Z., Dussipovb, E.S., Altynbekkyzya, A., Ashimovaa, D.I., Nurbeka, D.T., \& Urazymbetova, T.E. (2016). Non-Profit Ecological Organizations in the Function of the Realization of the Right to Freedom of Association and the Development of Civil Environmental Liability in Kazakhstan. International Journal of Environmental \& Science Education, 11(15), 7990-8005.

Alaghmand, S., \& Abdullah, R. (2012). GIS-Based River Basin Flood Modelling Using Hec-Hms And Mike11 - Kayu Ara River Basin, Malaysia. Journal of Environmental Hydrology, 20(8), 1-16.

Artun, H., \& Özsevgeç, T. (2016). A Study On The Evaluation Of The Applicability Of An Environmental Education Modular Curriculum. International Journal Of Environmental \& Science Education, 11(15), 7318-7347. 
Brennan, J.K., \& Lebeau, Y. (2004). The Role of Universities in the Transformation of Societies: An International Research Project London: Association of Commonwealth Universities.

Cunningham A.E, et. Al (2016). Professional Development Tools to Improve the Quality of Infant and Toddler Care: A Review of the Literature. U.S. Department of Health and Human Services Administration for Children and Families Office of Planning, Research \& Evaluation 330 C Street SW 4th Floor Washington, DC. Retrieved July 2017 from https://www.researchconnections.org/childcare/resources/29247?q=Pre+Experiment+de sign\#

Duffková, R. (2008). Evaluation of Management-Dependent Changes in the Water Regime of Extensive Grasslands. Journal of Soil \& Water Resources, 3(1), 1-11.

Fettahlıŏlua, P. Timur, S., \& Timur, B. (2016). Environmental Affective Dispositions Scale (EADS): The Study of Validity and Reliability and Adaptation to Turkish. International Journal Of Environmental \& Science Education, 11(10), 3179-3199.

Habiyakare, T., Nianqing, Z., \& Xinping, S. (2015). Assessment of contribution of major rivers inflow into the Dongting Lake, China. International Journal of Water Resources $\begin{array}{lll}\text { and Environmental } & \text { Engineering, } & \text { 7(8), }\end{array}$ https://doi.org/10.5897/IJWREE2015.0595

Iskandar D., \& Sugandi D (2015). Flood Mitigation Efforts In The Special Capital Region Of Jakarta. International Journal Of Conservation Science, 6(4), 685-696.

Linn, R.M., \& Rolim, S.B.A. (2015). Mapping Land Cover Classes in the Southern State of Rio Grande Do Sul, Brazil, Using Multiple Endmember Spectral Mixture Analysis (MESMA) Model Applied to Hyperion/EO-1 Hyperspectral Data. International Journal of Advanced Remote Sensing and GIS, 4(1), 990-1007. https://doi.org/10.23953/cloud.ijarsg.93

Meyer, W.B., \& Turner, B.L. (1998). Change in Land Use and Land Cover (A Global Perspective). Cambridge University Press, United Kingdom.

Mohsen, M., Iqbal, Z., Kumar, U., Ullah, W., \& Akash, O. (2013). Sustainable System Solutions: RAK Research and Innovation Center. International Journal of Sustainable Water \& Environmental Systems, 5(2), 67-76.

Ndofirepi, A.P., \& Cross, M. (2014). Transforming Epistemologies in the Postcolonial African University? The Challenge of the Politics of Knowledge. Journal of Education and Learning, 8(4), 291-298. https://doi.org/10.11591/edulearn.v8i4.119

Prasena, A., \& Shrestha, P. (2013). Assessing The Effects Of Land Use Change On Runoff In Bedog Sub Watershed Yogyakarta. Faculty of Geography UGM Indonesian Journal Geography, 45(1), 48-61.

Purwanto, E., Fatchan, A., Purwanto \& Soekamto, H. (2016). Development of Geography Text Books Used by Senior High School Teachers Case Study at East Java-Indonesia. 
Journal of Education and Learning, 5(1), 60-67. https://doi.org/10.5539/jel.v5n1p60

Rushayati, S.B., Alikodra, H.S., Dahlan, E.N., \& Purnomo, H. (2011). Pengembangan Ruang Terbuka Hijau Berdasarkan Distribusi Suhu Permukaan Di Kabupaten Bandung. Jurnal Forum Geografi, 25(1), 17-26.

Sefouhi, L., Kalla, M., \& Aouragh, L. (2010). Trends and Problems of Municipal Solid Waste Management in Batna City and Prospects for a Sustainable Development. International Journal of Sustainable Water \& Environmental Systems, 1(1), 15-20. https://doi.org/10.5383/swes.0101.004

Shivhare, V., Goel, M.K., \& Singh, C.K. (2014). Simulation of Surface Runoff For Upper Tapi Subcatchment Area (Burhanpur Watershed) Using SWAT. The International Archives of the Photogrammetry, Remote Sensing and Spatial Information Sciences, XL(8), 391-398. https://doi.org/10.5194/isprsarchives-XL-8-391-2014

Smith, K., \& Ward, R. (1998). Floods, Physical Processes and Human Impacts. Chichester, USA: John Wiley \& Sons Ltd.

Sukojo, B.M. (2003). Penggunaan Metode Analisa Ekologi dan Penginderaan Jauh Untuk Pembangunan System Informasi Geografis Ekosistem Pantai. Jurnal MAKARA, Sains, 7(1), 32-37.

Suriya, I.G., Iskander, R.G., \& Rimma, N.S. (2015). The Feature of Scientific Explanation in the Teaching of Chemistry in the Environment of New Information of School Students' Developmental Education. International Journal of Environmental \& Science Education, 11(4), 349-358.

Ting, K.L., \& Siew, N.M. (2014). Effects of Outdoor School Ground Lessons on Students' Science Process Skills and Scientific Curiosity. Journal of Education and Learning, 3(4), 96-107. https://doi.org/10.5539/jel.v3n4p96

Wiryono. (2007). Menuju Pembangunan Berkelanjutan, Membangun Tanpa Merusak Lingkungan. Seminar Pembangunan Berkelanjutan, Bengkulu. Mei 2007.

\section{Copyright Disclaimer}

Copyright for this article is retained by the author(s), with first publication rights granted to the journal.

This is an open-access article distributed under the terms and conditions of the Creative Commons Attribution license (http://creativecommons.org/licenses/by/3.0/). 